\title{
ЗАБЕЗПЕЧЕННЯ ЕФЕКТИВНОСТІ СИСТЕМИ КОНТРОЛІНГУ В ГОТЕЛЬНО-РЕСТОРАННОМУ БІЗНЕСІ: АСПЕКТНИЙ АНАЛІЗ
}

\section{ENSURING THE EFFICIENCY OF THE CONTROLLING SYSTEM IN THE HOTEL AND RESTAURANT BUSINESS: ASPECT ANALYSIS}

\author{
Гончар Лілія Олександрівна \\ кандидат економічних наук, доцент, \\ Київський національний університет культури і мистецтв \\ ORCID: https://orcid.org/0000-0001-5621-0910 \\ Батченко Людмила Вікторівна \\ доктор економічних наук, професор, \\ Київський національний університет культури і мистецтв \\ ORCID: https://orcid.org/0000-0001-6975-5813 \\ Аухімік Ольга Вячеславівна \\ магістр, \\ Київський національний університет культури і мистецтв \\ ORCID: https://orcid.org/0000-0002-9358-3609 \\ Honchar Liliia, Batchenko Liudmyla, Aukhimik Olha
Kyiv National University of Culture and Arts
}

\footnotetext{
У статті розкрито поняття «контролінг» та контекст, який його характеризує. Розглянуто систему контролінгу в готельно-ресторанному бізнесу і її особливості, зважаючи на протікання бізнес-процесів на підприємстві. Здійснено аналіз структурної системи функціонування системи контролінгу в закладах гостинності. Визначено процеси, які повинна регулювати система контролінгу. Особливу увагу приділено результатам аналізу ефективності застосування трудових ресурсів на прикладі конкретного підприємства сфрери гостинності, на основі якого визначено як зовнішнє середовище вплинуло на досліджувані показники. На основі проведеного аналізу здійснено порівняльний аналіз середньої зарплати на території України за різними показниками. Враховуючи результати аспектного аналізу, зроблено висновки, що для сорери управління трудовими ресурсами необхідно створення ефективної системи контролінгу на підприємстві.

Ключові слова: контролінг, система контролінгу, готельно-ресторанний бізнес, управління трудовими ресурсами, управління фрінансовими ресурсами, управління виробничими ресурсами.
}

В статье раскрыто понятие «контроллинг» и характеризующий его контекст. Рассмотрена система контроллинга в гостинично-ресторанном бизнесе и ее особенности, учитывая протекание бизнес-процессов на предприятии. Осуществлен анализ структурной системы функционирования системы контроллинга в заведениях гостеприимства. Определены процессы, которые должна регулировать система контроллинга. Особое внимание уделено результатам анализа эсфрективности применения трудовых ресурсов на примере конкретного предприятия сореры гостеприимства, на основе которого определено, как внешняя среда повлияла на исследуемые показатели. На основе проведенного анализа проведен сравнительный анализ средней зарплаты на территории Украины по разным показателям. Учитывая результаты аспектного анализа, сделаны выводы, что для сферы управления трудовыми ресурсами необходимо создание эффективной системы контроллинга на предприятии.

Ключевые слова: контроллинг, система контроллинга, гостинично-ресторанный бизнес, управление человеческими ресурсами, управление финансовыми ресурсами, управление производственными ресурсами.

The article is devoted to the implementation of theoretical and applied analysis of key aspects of the controlling system in the hotel and restaurant business. Lack of effective system of personnel management in domestic hospi- 
tality enterprises and especially controlling of personnel, is a significant factor that leads to the wrong management decisions. Thus, unskilled and erroneous actions of top management can bring businesses to the brink of bankruptcy. Today, during the pandemic and instability of the hotel and restaurant business, the relevance of the topic is due to the high importance of building quality management systems at the enterprise, on which depends the effectiveness of their activities. Accordingly, this article reveals the concept of "controlling" and its context that characterizes it. The controlling system in the hotel and restaurant business and its features are considered, taking into account the course of business processes at the enterprise. The analysis of the structural system of functioning of the controlling system in hospitality establishments is carried out. The processes that should be regulated by the controlling system are defined. Particular attention is paid to human resource management, which is an important aspect of the enterprise. An analysis of the effectiveness of the use of labor resources on the example of a particular enterprise in the hospitality industry, which is defined as the external environment influenced the studied indicators. Based on the results of the analysis, a comparative analysis of the average salary in Ukraine on various indicators, which showed the inconsistency of the obtained indicators with state requirements. The necessity of creating a controlling system at the enterprises of hotel and restaurant business is substantiated. Taking into account the results of the aspect analysis, it is concluded that for the sphere of labor management it is necessary to create an effective controlling system at the hotel and restaurant business, which should take into account the opportunities and threats of the enterprise and be adaptable to environmental changes.

Keywords: controlling, controlling system, hotel and restaurant business, human resources management, financial resources management, production resources management.

Постановка проблеми. Сучасні ринкові умови диктують підприємствам нові правила роботи та вимагають удосконалення процесу управління підприємством. Тому важливо організувати на підприємстві систему контролінгу для оптимізації та підвищення ефрективності управління мікроекономікою в готельно-ресторанному бізнесі. Контролінг - один із нових способів управління підприємством, метою якого $€$ підтримка майбутнього розвитку підприємства. Сьогодні, під час пандемії, коли ситуація в країні та світі є невизначеною, важливо без великих затрат позбутися кризової ситуації. Ось чому для встановлення стійкого розвитку готельно-ресторанного бізнесу $є$ досить актуальним питання підвищення ефективності системи управління. Виходячи з цього, проблема впровадження систем управління в сучасний бізнес стала дуже важливою. Саме тому для забезпечення правильності управлінських рішень необхідним $є$ впровадження ефрективної системи контролінгу на підприємствах сорери гостинності.

Аналіз останніх досліджень і публікацій. Глибинні та різновекторні теоретико-методологічні та прикладні дослідження 3 питань організації та забезпечення ефективності контролінгу в сучасних умовах ведення бізнесу мають місце в працях ряду вітчизняних і зарубіжних науковців, зокрема О. Ананькіної, А. Борисова [1], А. Вайсмана [2], В. Герасименко [3], А. Дайле, Н. Данілочкіної [4], Е. Майєра [5; 6], Р. Манна [6], М. Пушкара, Д. Хана [7], Х. Фольмута [8], Ч. Хорнгрена.

Слід зауважити, що сучасні трактування поняття контролінг різними науковцями зосереджуються на різновекторних (але не діаметрально протилежних) спрямуваннях від- повідно до напрямку його застосування, як одного із методів підвищення ефективності управління в тому чи іншому аспекті. Відповідно у процесі аналізу відомих визначень контролінгу простежується так зване «нарощування» значення і змісту цього поняття.

Виділення невирішених раніше частин загальної проблеми. Незважаючи на широту та глибинність досліджень поняття контролінгу та системи його впровадження та орієнтуючись на трансформацію й динамічність розвитку готельно-ресторанного бізнесу та вплив кризової ситуації, актуальним постає питання ґрунтовного теоретико-аналітичного та прикладного дослідження ключових аспектів системи контролінгу безпосередньо для підприємств сорери гостинності.

Формулювання цілей статті. Метою дослідження $€$ здійснення теоретико-прикладного аналізу ключових аспектів системи контролінгу в готельно-ресторанному бізнесі.

Виклад основного матеріалу дослідження. В теперішньому світі, а особливо в бізнесі, відбулось переосмислення ролі та значення менеджменту, що викликало появу такої дисципліни як «контролінг». Раніше управління підприємством пов'язували тільки 3 вирішенням поточних проблем та справ на підприємстві, а в умовах нестабільності та загострення конкурентної боротьби, управління стали пов'язувати з успішністю та тривалістю існування підприємства.

Незважаючи на широку популяризацію контролінгової діяльності як комплексного процесу в цілому та безпосередньо і частого виживання самого поняття «контролінг» в сучасних умовах ведення бізнесу, як в Україні, так і в світі немає однозначно сорормованого 
і визначеного єдиного трактування наукової категорії «контролінг».

Відповідно до наукових досліджень цього напряму, можна здійснити уніфрікацію і консолідацію трактувань вітчизняних і зарубіжних вчених та визначити, що контролінг - це система управління одним або декількома процесами підприємства, що спрямована на досягнення та збереження стратегічної цілі і включає в себе здійснення інфрормаційного забезпечення, оцінку, координацію, узгодження, оптимізацію та контроль діяльності усіх фрункціонально-управлінських одиниць за виконанням стратегічного плану.

Відповідно предметом контролінгу є мікроекономічні процеси і явища на підприємстві та макроекономічні процеси в країні, які впливають на економіку підприємства. Контролінг, як система, повинен бути запроваджений з метою орієнтування управлінського процесу на виконання цілей та задач підприємства. Загалом система контролінгу представляє собою єдиний зв'язок компонентів планування, контролю, перевірки та обліку задля ефективного використання ресурсів, збільшення прибутку i покращення якості менеджменту.

Впровадження контролінгової діяльності на підприємствах готельно-ресторанного бізнесу на сьогодні є особливо актуальним. Для забез- печення перспективного розвитку контролінгу в ГРБ, а саме для зростання потоків інвестицій та сприяння збільшенню західних технологій управління, повинно бути стійке зростання економічного становища в країні [9].

Контролінг виступає як одна із специсрічних фрункцій управління, в основі якої покладено ефрективне керування підприємством та забезпечення його життя в конкурентних умовах. Так, мета контролінгу виявляється в есрективному підтриманні фрункціонування підприємства за рахунок своєчасних та правильних управлінських рішень прийнятих вищим керівництвом. Відповідно на підприємстві повинен бути забезпечений ефективний комплекс контролінгових заходів у всіх напрямках його діяльності, що загалом формують систему контролінгової діяльності закладу готельно-ресторанного бізнесу.

Зважаючи на особливості протікання бізнес-процесів на підприємствах готельно-ресторанного бізнесу та враховуючи структуру і зміст їх господарської діяльності, виникає необхідність проектування структурної моделі фрункціонування системи контролінгу у закладах готельно-ресторанного бізнесу, яка, в свою чергу, повинна мати комплексний характер, охоплювати ключові напрямки фрункціонування підприємства та загалом мати цілісну і єдину структуру (рис. 1) [10].

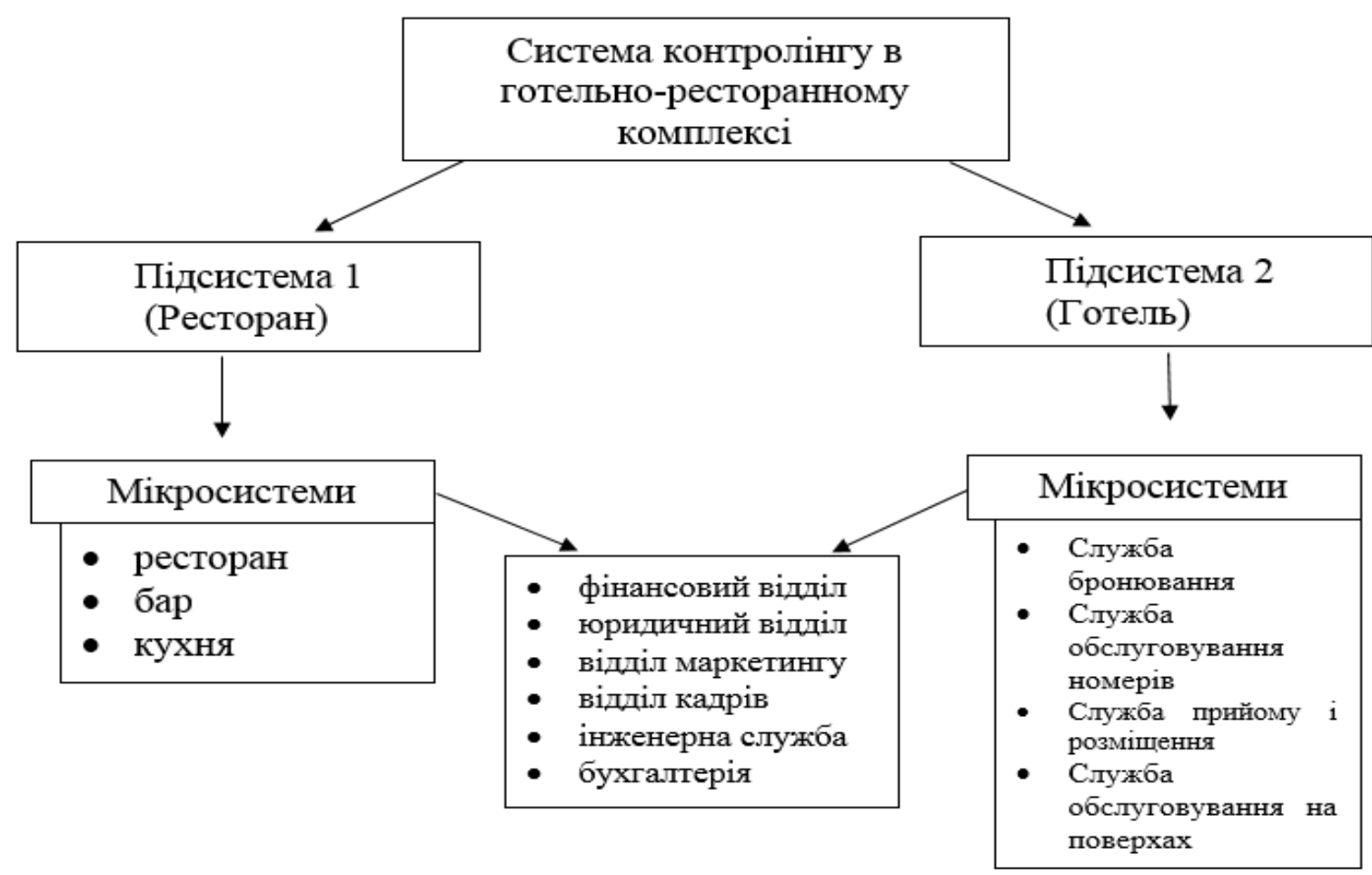

Рис. 1. Структурна модель функціонування системи контролінгу в закладах готельно-ресторанного бізнесу 
Аналізуючи особливості представленої на рис. 1 структурної моделі фрункціонування системи контролінгу в закладах готельно-ресторанного бізнесу, видно, що вона базується на двох окремих китах (підсистемах) - підсистема 1 (ресторан) і підсистема 2 (готель), які, в свою чергу, ґрунтуються на відповідних мікросистемах. Під мікросистемами маємо на увазі служби, які входять до складу виключно ресторану або готелю. Комплексність та особливість представленої моделі полягає у тому, що, окрім врахування базових служб (мікросистем) у розрізі двох ключових підсистем, вона акцентує увагу на їх нерозривності із ще однією підсистемою, яка включає в себе спільні адміністративно-управлінські служби і без якої фрункціонування готельно-ресторанного комплексу як єдиного цілісного і злагодженого механізму $є$ просто неможливим. Така модель функціонування системи контролінгу у закладах готельноресторанного бізнесу дозволяє максимально едрективно як впровадити вперше, так і удосконалити існуючу систему контролінгу на всіх структурно-організаційних рівнях підприємства та успішно забезпечити управління зовнішніми та внутрішніми ризиками.

В розрізі цієї моделі система контролінгу повинна регулювати процеси, які відбуваються в закладах ссрери гостинності як в підсистемі 1 (ресторан), так і в підсистемі 2 (готель) разом (таблиця 1), зокрема, управління фрінансовими, виробничими та трудовими ресурсами.

Трудові ресурси $€$ надзвичайно важливим аспектом у діяльності підприємства, що поряд 3 аналізом всього, потребує більш фрундаментального, системного та практичного аналізу. На сьогодні, питання контролінгу персоналу в сорері гостинності $\epsilon$ недостатньо широко розглянутим, що в свою чергу дає змогу ствердити, що трудові ресурси в діяльності готельно-ресторанного комплексу не розглядалися в єдиній системі цілей підприємства. Варто зазначити, що трудові ресурси в готельно-ресторанному бізнесі - це базис, головна цінність підприємства на якому зараз рухається сорера гостинності, що має бути спрямований на отримання кінцевих результатів.

Відповідно, в розрізі управління трудовими ресурсами, має бути забезпечено максимальну мотивацію персоналу до високопродуктивної праці, зокрема, за рахунок системи матеріального стимулювання (заробітної плати) та нематеріальних чинників (підвищення кваліфрікації за допомогою різних курсів, майстер-класів та ін.).

3 метою поглиблення та практичності аналізу системи контролінгу готельно-ресторанного бізнесу за визначеними аспектами слід розглянути один із діючих регіональних закладів - готельно-ресторанний комплекс «Машівський бір», що розташований у Волинській області та є одним із кращих закладів гостинності на території Любомльської ОТГ.

Готельно-ресторанний комплекс «Машівський бір» функціонує на основі трьох ФОП, 3 яких ФОП Лис Петро Григорович оподатковується за загальною системою, а ФОП Матвійчук Микола Миколайович та ФОП Лис Лариса Василівна - $€$ фрізичними-особами підприємцями 2 групи.

Ефеектиність та дієвість роботи готельноресторанного комплексу «Машівський бір» напряму залежить від мотивації та результативності роботи персоналу на підприємстві. Для того, щоб оцінити рівень використання трудового потенціалу готельно-ресторанного підприємства «Машівський бір» в цілому $\epsilon$ доцільним здійснити аналіз ефективності використання трудових ресурсів підприємства.

Відповідно до проведених розрахунків у таблиці 1 на основі даних, що були отримані на підприємстві, можна ствердити, що на підприємстві середня чисельність персоналу в 2019 році збільшилась на 16\% в порівнянні 32018 роком, але а в 2020 році - зменшилась на 12 чоловік, що становить на 41\% менше ніж у 2019 році. Основною причиною скорочення чисельності персоналу є зменшення чистого доходу, який в свою чергу, спричинений обмеженнями, які держава застосувала для зупинення поширення пандемії на території України.

Розрахунки продуктивності праці показали, що у 2019 році показники впали на $37 \%$ відносно 2018 роком, а у 2020 році збільшилась на 2 \% в порівнянні 32019 роком. Незважаючи на ситуацію в країні на 2020 рік, підприємству вдалося зберегти показник продуктивності праці на рівні показника 2019 року, що не можна сказати про 2019 рік.

Аналізуючи фонд оплати праці (ФОП), можна сказати, що у 2018 та 2019 роках цей показник залишився незмінним, відповідно у 2020 році під впливом зовнішніх фракторів ФОП скоротився на 628882,39 грн., що становить 43\% від показника 2019 року. Якщо аналізувати рівень ФОП, то у 2019 році він зріс на $19 \%$, що становить $71 \%$, але у 2020 році його рівень майже залишився на такому ж рівні, що у 2019 році, лише знизився на $2 \%$.

Для аналізу рівня середньомісячної зарплати на підприємстві слід порівняти його показники 3 аналогічними показниками статистичних даних по Україні та Волинської області (таблиця 2). 


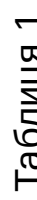

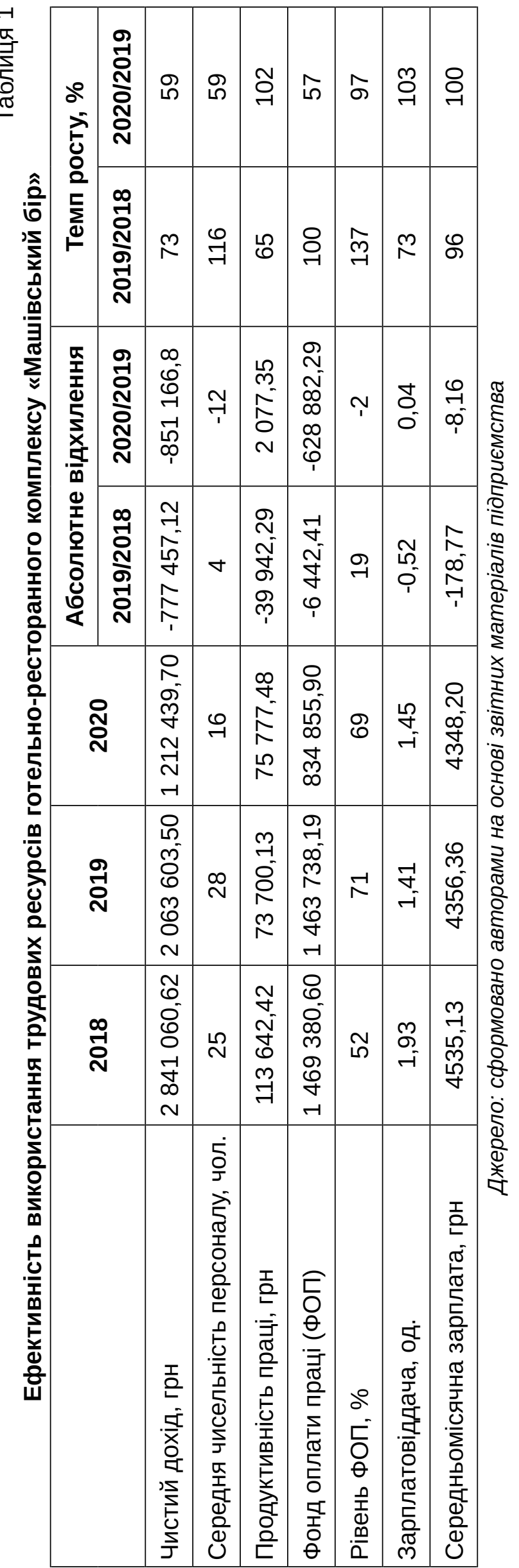

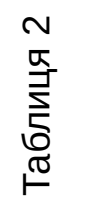

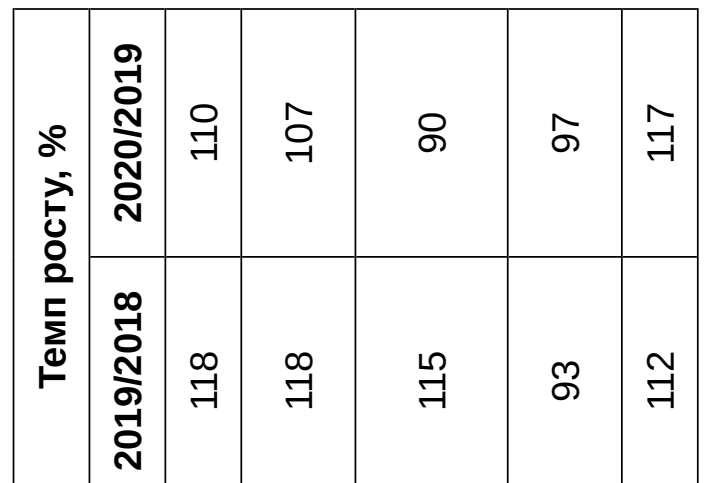

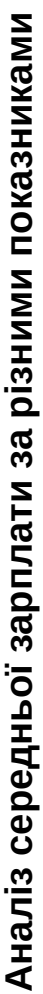

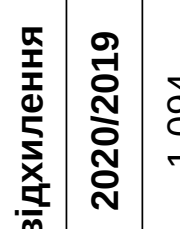

产

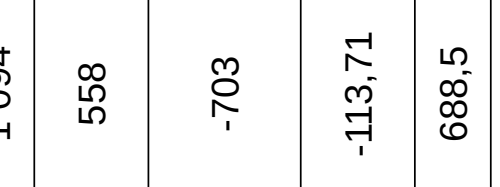

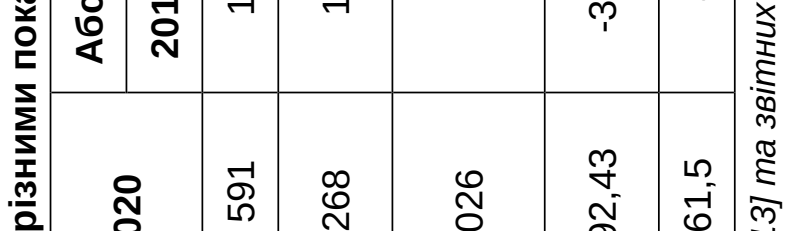

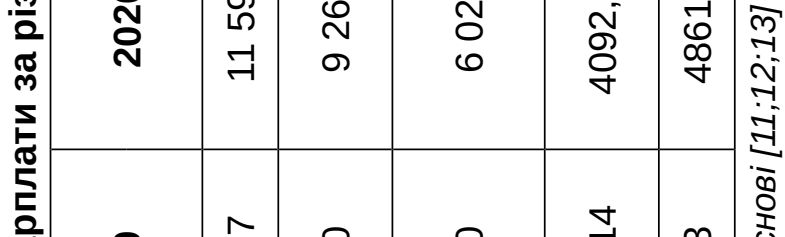

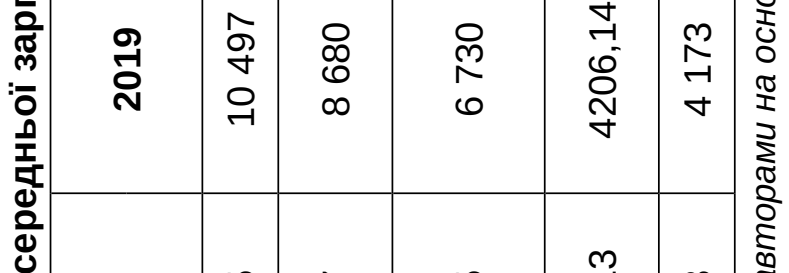

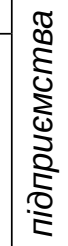

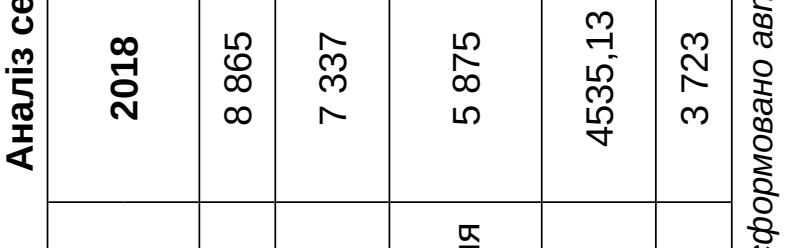

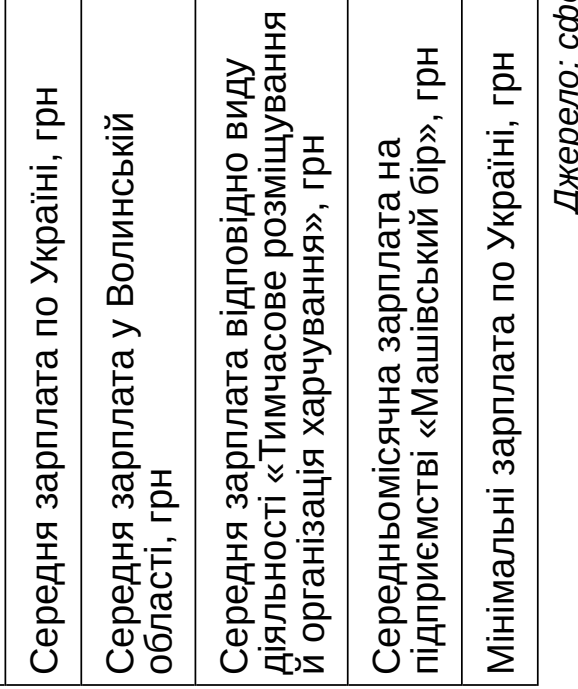

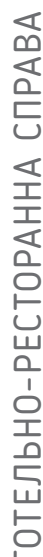


Відповідно до проведеного аналізу видно, що середня зарплата по Україні зростала кожного року, у 2019 році на 18\% відносно 2018 року, а у 2020 році на 10\%. Середня зарплата у Волинській області також зросла: у 2019 році на 18\%, а у 2020 році на $7 \%$. Не зважаючи на те, що у 2020 році почалась пандемія та весь світ, Україна в тому ж числі, зупинились на деякий час, заробітна плата все одно продовжувала зростати, хоча в трішки повільнішому темпі.

Показник середньої зарплати відповідно виду діяльності «Тимчасове розміщування й організація харчування» дозволяє проаналізувати зарплатню працівникам у сфрері послуг, що у 2018 році становить 5875 грн., у 2019 році - 6730 грн., що на 15\% більше порівняно з 2018 роком, а у 2020 році цей показник становить 6026 грн., тобто знизився на 10\%. Негативна динаміка пояснюється складним становищем сорери гостинності у 2020 році, що напряму залежала від пандемії коронавірусу, що поширювалась на території України.

Якщо порівнювати середньомісячну зарплату на підприємстві та мінімальну заробітну плату, то можна сказати, що в 2018 році заробітна плата становить 4535,13 грн, яка відповідає сумі мінімальної зарплати та перевищує іï. У 2019 році середньомісячна зарплата становить 4356,36 грн., що задовольняє вимоги законодавства по мінімальній зарплаті в Україні. Але у 2020 році цей показник не досягає норми та становить 4348,20 грн., та $€$ меншим ніж встановлена мінімальна заробітна плата по Україні - 4861,50 грн., що спричинено зовнішніми чинниками, а саме карантинними обмеженнями на території України.

Відповідно до рисунку 2 можна ствердити, що показник середньомісячної зарплати в готельно-ресторанному комплексі «Машівський бір» має негативну динаміку і у 2019, і у 2020 роках, на відміну від динаміки середньої зарплати по Україні та Волинській області. Також з кожним роком змінювалась сума мінімальної заробітної плати, у 2018 та 2019 роках рівень середньої зарплати в ГРК відповідав мінімальній зарплаті, але у 2020 році на підприємство не змогло забезпечити виплати мінімальної зарплати, що в свою чергу $\epsilon$ однією з причин до створення системи контролінгу на підприємстві, для забезпечення есрективного та результативного управління фрінансами та ресурсами підприємства.

На основі проаналізованих фрінансових показників діяльності готельно-ресторанного комплексу «Машівський бір» можна дійти висновку, що для підприємства «Машівський бір» $€$ велика необхідність до змін форми господарювання та системи управління в середині підприємства, а саме системи контролінгу, для забезпечення ефрективного та рентабельного фрункціонування підприємства на ринку.

Таким чином, аспектний аналіз показав, що готельно-ресторанний комплекс «Машівський бір» потребує змін усередині підприємства, зокрема, змін щодо організації трудових ресурсів, що $є$ на підприємстві. Тому, щоб підвищити ефективність використання трудового потенціалу ГРК «Машівський бір» необхідно
Мініма льні зарплата по Україні, грн

Середньомісячна зарплата на пі дприємстві «Ма шівський...

Середня зарплата відповідно виду діяльності «Тимчасове..

Середня за рплата уВолинській обла сті , грн

Середня за рплата по Україні, грн

$$
\text { - } 2020 \quad \mathbf{2 0 1 9}
$$

Рис. 2. Динаміка середньої зарплати за різними показниками

Джерело: сформовано автором на основі [11; 12; 13] та звітних матеріалів підприємства 
врахувати негативний вплив зовнішнього середовища за допомогою налагодженої системи контролінгу, що дозволить своєчасно виявляти майбутні загрози та можливості.

Також необхідно враховувати те, що персонал на підприємстві має велику та активну частку у суспільному виробництві, тому доцільно зауважити, що для підвищення ефрективності трудового потенціалу підприємства необхідно спрямовувати увагу на мотивацію персоналу, основним засобом якої $€$ заробітна плата. На підприємстві «Машівський бір» цей аспект має негативну динаміку по роках та $є$ необхідним до удосконалення, що в свою чергу $є$ наглядним прикладом того, що контролінг персоналу українськими підприємствами готельно-ресторанного бізнесу поки що в практиці майже не застосовується. Керівникам необхідно пам'ятати, що успішність кожного підприємства ґрунтується на зацікавленості персоналу виконувати свої обов'язки відповідально та якісно для розвитку цього самого підприємства.
Висновки. На сьогоднішній день підприємства готельно-ресторанного бізнесу в Україні стикаються 3 серйозними проблемами фрормування ефективних систем контролінгу за трудовими ресурсами та трудовим потенціалом. Саме тому є потреба у розвитку потенціалу персоналу підприємств сорери гостинності не тільки у теоретичних знаннях, а й на практиці. Підприємствам необхідно звернути увагу на створення та побудову ефективних систем розвитку та навчання персоналу, що вже результативно діють закордоном. Отже, для готельно-ресторанного бізнесу в Україні цей аспект діяльності підприємства є важливим, особливо в кризовий період для країни, коли, в першу чергу, необхідно підвищувати ефективність використання трудових ресурсів. Відповідно, для того, щоб забезпечити підтримку в прийнятті управлінських рішень на підприємствах сорери гостинності стосовно формування, використання та розвитку персоналу необхідно забезпечити фрункціонування ефрективної системи контролінгу.

\section{СПИСОК ВИКОРИСТАНИХ ДЖЕРЕЛ:}

1. Борисов А.Б. Большой экономический словарь. Москва : Книжный мир, 2010. 860 с.

2. Вайсман А. Стратегия маркетинга: 10 шагов к успеху; Стратегия менеджмента: 5 фракторов успеха : [Пер. с нем.]. Москва : АО «Интерэксперт» : Экономика, 1995. 343 с.

3. Герасименко В.М. Роль контролінгу в системі управління високотехнологічним підприємством. Вісник економіки транспорту і промисловості. 2018. № 62. С. 285-289.

4. Данилочкина Н.Г. Контроллинг как инструмент управления предприятия. Москва : Аудит, ЮНИТИ, 2001. 279 c.

5. Майер Э. Контроллинг как система мышления и управления. Москва : Финансы и статистика, 1992. 96 c.

6. Манн Р., Майнер Э. Контроллинг для начинающих. Система управления прибылью : Пер. с нем. Ю.Г. Жукова / Под ред. и с предисл. д-ра экон. наук В.Б. Ивашкевича. 2-е изд., перераб. и доп. Москва : Финансы и статистика, 2004. 304 с.

7. Хан Д. Планирование и контроль: концепция контроллинга [пер. с нем.]. Москва : Наука, 1978.

8. Фольмут Х. Инструменты контроллинга от А до Я. Москва : Финансы и статистика, 2003.

9. Микитюк Н.О. (2006) Створення системи контролінгу як спосіб підвищення есрективності управління підприємствами. Менеджмент та підприємнитво в Україні: етапи становлення і проблеми розвитку. URL: http://ena.lp.edu.ua:8080/bitstream/ntb/30370/1/Vis_570_Menedgment.\%2042-46.pdf

10. Гончар Л.О., Аухімік О.В. (2020) Система контролінгу в готельно-ресторанному бізнесі: теоретико-прикладний аспект. The 4th International scientific and practical conference "Fundamental and applied research in the modern world" (November, 18-20) BoScience Publisher, Boston, USA. 1036 p. P. 433-439. URL: https://sci-conf.com.ua/iv-mezhdunarodnaya-nauchno-prakticheskaya-konferentsiya-fundamental-and-appliedresearch-in-the-modern-world-18-20-noyabrya-2020-goda-boston-ssha-arhiv/

11. Середня заробітна плата за видами економічної діяльності по місяцях (н.д.). URL: http://www.ukrstat.gov.ua/ operativ/operativ2005/gdn/Zarp_ek_m/Zp_ek_m_u/arh_zpm_u.html

12. Середньомісячна заробітна плата штатних працівників за видами економічної діяльності (н.д.). URL: http://www.ukrstat.gov.ua/operativ/operativ2021/gdn/szpshp/arh_szp_ed_u.html

13. Середня заробітна плата за регіонами за місяць (н.д.). URL: http://www.ukrstat.gov.ua/operativ/ operativ2005/gdn/reg_zp_m/reg_zpm_u/arh_zpm_u.htm 


\section{REFERENCES:}

1. Borisov A.B. (2010) Bol'shoy ekonomicheskiy slovar' [The Big Economic Dictionary]. Moscow: Book World. (in Russian)

2. Vaysman A. (1995) Strategiya marketinga: 10 shagov k uspekhu; Strategiya menedzhmenta: 5 faktorov uspekha [Marketing strategy: 10 steps to success; Management strategy: 5 success factors]: [Trans. from German]. Moscow: Interexpert JSC: Economics, Success. (in Russian)

3. Herasymenko V. M. (2018) Rol' kontrolinhu v systemi upravlinnya vysokotekhnolohichnym pidpryyemstvom [The role of controlling in the management system of a high-tech enterprise]. Bulletin of Transport and Industry Economics, no. 62, pp. 285-289. (in Ukrainian)

4. Danilochkina N.G. (2001) Kontrolling kak instrument upravleniya predpriyatiya [Controlling as an enterprise management tool]. Moscow: Audit, UNITY. (in Russian)

5. Mayer E. (1992) Kontrollihg kak systema myshleniya y upravleniya [Controlling as a system of thinking and management]. Moscow: Finance and statistics. (in Russian)

6. Mann R., Mayner E. (2004) Kontrolling dlya nachinayushchikh. Sistema upravleniya pribyl'yu [Controlling for beginners. Profit Management System]: Per. s nem. Yu.G. Zhukova / Pod red. i s predisl. d-ra ekon. nauk V.B. Ivashkevicha. 2-e izd., pererab. i dop. statistika [Trans. from German Yu.G. Zhukova / Ed. And with a foreword. Dr. Econ. sciences V.B. Ivashkevich. 2nd ed., Redesign. and additional]. Moscow: Finance and statistics. (in Russian)

7. Han D. (1978) Planirovanie i kontrol: kontseptsiya kontrollinga [Trans. from German]. Moscow: Science. (in Russian)

8. Folmut H. (2003) Instrumentyi kontrollinga ot A do Ya. Moscow: Finance and statistics. (in Russian)

9. Mykytyuk N.O. (2006) Stvorennya systemy kontrolinhu yak sposib pidvyshchennya efektyvnosti upravlinnya pidpryyemstvamy [Creating a controlling system as a way to increase the efficiency of enterprise management]. Management and entrepreneurship in Ukraine: stages of formation and development problems, pp. 42-46. Available at: http://ena.Ip.edu.ua:8080/bitstream/ntb/30370/1/Vis_570_Menedgment.\%2042-46.pdf (accessed 28 October 2021). (in Ukrainian)

Gonchar L.O., Auximik O.V. (2020) Systema kontrolingu v gotelno-restorannomu biznesi: teoretyko-prykladnyj aspekt. The 4th International scientific and practical conference "Fundamental and applied research in the modern world" (November, 18-20) BoScience Publisher, Boston, USA. 1036 p. Pp. 433-439. Available at: https://sci-conf.com.ua/iv-mezhdunarodnaya-nauchno-prakticheskaya-konferentsiya-fundamental-and-applied-research-in-the-modern-world-18-20-noyabrya-2020-goda-boston-ssha-arhiv/ (in Ukrainian)

10. Serednya zarobitna plata za vydamy ekonomichnoyi diyalnosti po misyacyax [Average salary by type of economic activity by months]. Available at: http://www.ukrstat.gov.ua/operativ/operativ2005/gdn/Zarp_ek_m/Zp_ ek_m_u/arh_zpm_u.html

11.Serednomisyachna zarobitna plata shtatnyx pracivnykiv za vydamy ekonomichnoyi diyalnosti [Average monthly salary of full-time employees by type of economic activity]. Available at: http://www.ukrstat.gov.ua/operativ/ operativ2021/gdn/szpshp/arh_szp_ed_u.html

12. Serednya zarobitna plata za regionamy za misyacz [Average salary by region per month]. Available at: http://www.ukrstat.gov.ua/operativ/operativ2005/gdn/reg_zp_m/reg_zpm_u/arh_zpm_u.htm 